\title{
High Employment Without Inflation: On the Attainment of Admirable Goals
}

\author{
by ROGER W. SPENCER
}

\begin{abstract}
H IGH EMPLOXMENT and price stability are two of this country's foremost economic goals. In contrast to the early part of the $1960^{\prime} \mathrm{s}$ when prices were relatively stable but unemployment was high, and the latter part of that decade when unemployment was low but inflation was rapid, the early 1970 's have been marked both by high unemployment rates and by rapid inflation. Since the adoption by the Congress in 1946 of goals calling for the achievement of maximum purchasing power and full employment, the simultaneous realization of price stability and full employment has been rare.
\end{abstract}

These goals were reaffirmed by the Joint Economic Committee (JEC) in a recent Report." The Committee recommended that "The President and Congress should adopt as a longuterm objective the twin goals of an unemployment rate no higher than 3 per cent and an annual increase in the GNP deflator of no more than 2 per cent."

In only two years since 1946 have the Committee's employment and price stability goals been achieved simultaneously. In 1952 and 1953 an unemployment rate of 3 per cent or less and a rise in prices of less than 2 per cent were attained. Moderate monetary growth at a 3.7 per cent amual rate in the 1951-53 period facilitated the attainment of the inflation goal. Employment as a proportion of the labor force in 1952 and 1953 was enhanced by the fact that many

1"Roport of the Joint Economic Committee, Congress of the United States, on the February 1971 Economic Report of the President," (Washington, D. C., 1971 Joint Economic Report, U. S. Government Printing Office, 1971), p. 34 .

2labid. Representative Richard Bolling (Missouri) rejects the increase in prices of 2 per cent as being inconsistent with the 1946 Employment Act's objective of stable prices. potential young workers were in the armed forces (proportionally more than during the Vietnam War). Moreover, there were fewer of these young individuals (whose unemployment rate is typically higher than the average) than usual because of the low birth rates of the $1930^{\circ}$ s.

Many of the conditions surrounding the 1952-53 attainment of the employment and price goals do not exist presently and are not likely to exist in the near future. For example, young inexperienced workers are expected to enter the labor force at more rapid rates than during the early 1950 's for some time to come. Moreover, the money stock has expanded at a much more rapid rate in recent years than in the early 1950's. Thus, the Committee's endorsement of stable prices and a 3 per cent unemployment rate appears somewhat optimistic. Stabilization policy efforts to achieve such a low rate of unemployment could prove quite costly in terms of inflationary pressures. Low rates of unemployment could be achieved without aggravating inflation, however, by the adoption of measures designed to remove constraints on the functioning of labor markets.

This article examines the reasons for the occurrence and duration of unemployment, and, given this analysis, explores ways in which unemployment might be reduced without generating excessive inflationary pressures. The emphasis on unemployment reflects the fact that over the past twenty-five years, the Committee's 3 per cent unemployment rate target has not been attained as often as the 2 per cent per year price target (see the following chart).

Unemployment has long been described as arising from frictional, structural, and "inadequate demand" 


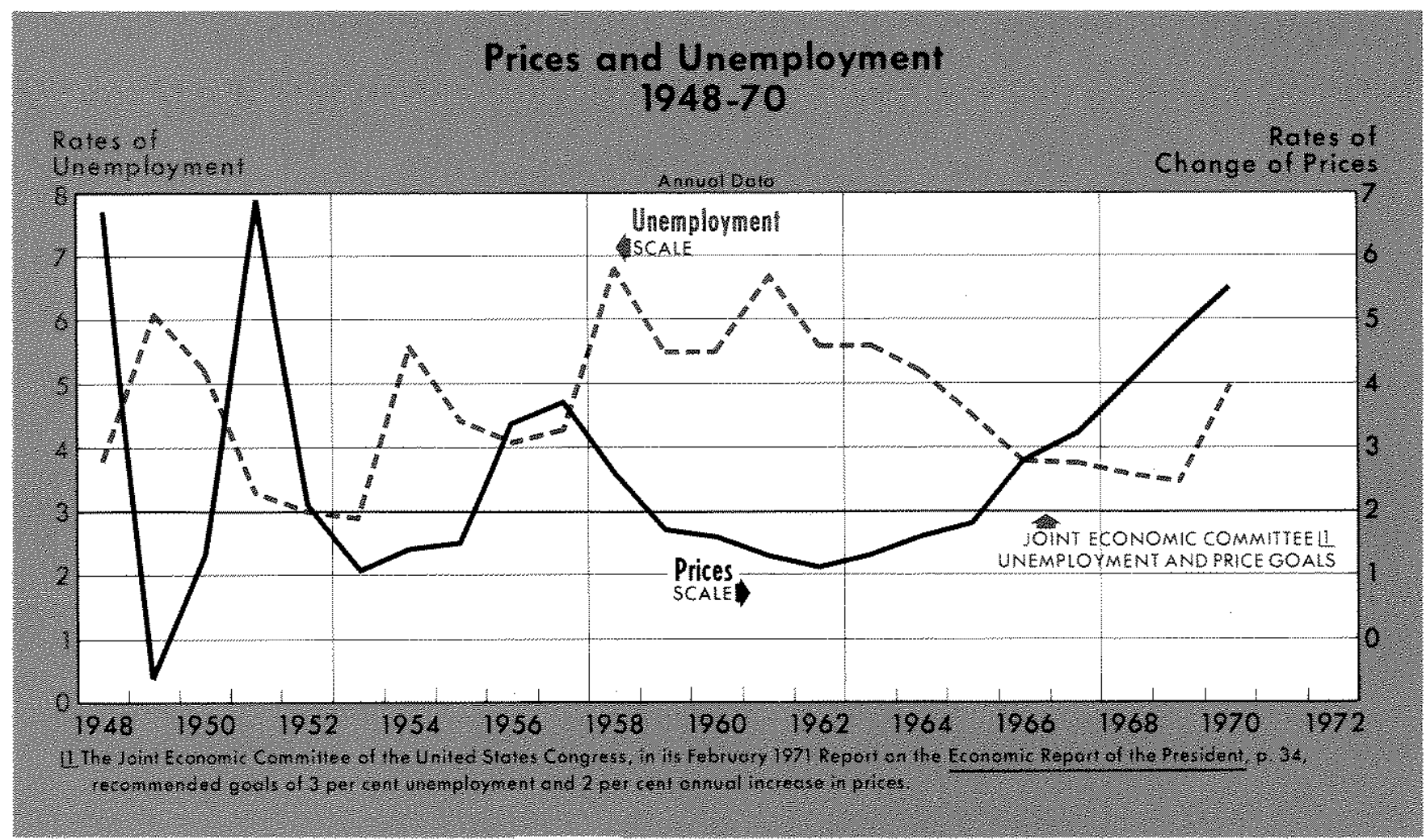

faetors, along with wage-price inflexibility. More recently, a theory of unemployment based on job information and relocation costs has emerged. This article investigates the unemployment issue through integration of these basic approaches.

The first section of the article explains why there is unemployment. The explanation is facilitated by spelling out conditions under which the unemployment rate would be equal to zero. This euphoric situation is developed to make a clear contrast with the actual world in which some unemployment inevitably exists. The underlying cause of real world unemployment is the fact that job information and relocation costs are positive. Next, a "normal" unemployment rate and the reasons for deviations from it are explored." The term "normal rate" of unemploy. ment does not imply that such unemployment is either desirable or immutable. One of the principal objectives of the advancement of the normal rate concept is to determine methods of lowering such a rate.

The second major section of the article outlines ways in which the rate of unemployment could be

"The "normal" unemployment rate, which has also been termed the "natural" rate, the "warranted" rate, and the "full employment" rate, is not a constant, but can vary over a short period with changes in the institutional setting of the labor market. reduced without aggravating inflation. The roles of legislative, fiscal and monetary policies with regard to employment are analyzed in this context. Finally, the econometric model of this Bank is used in the third section to examine possible future patterns of economic adjustment to alternative monetary policies designed to achieve the Committee's economic goals. The model draws on data from a period in which labor market restrictions were little different from what may be expected in the near future. Through simulation techniques, the model suggests that accelerating inflation would be required to achieve and maintain an unemployment rate near 3 per cent.

\section{WHY UNEMPLOYMENT:}

Unemployment is usually considered undesirable from both the social and private points of view. Yet, there has always been some unemployment. Contrasting a hypothetical world in which there is no unemployment, with the real world, in which positive costs of information and relocation as well as frictional, structural, and aggregate demand-related forces combine to foster unemployment, should provide insight into the problem.

\section{A World of Zero Unemployment}

In developing an illustration of a hypothetical world in which there exists no unemployment, that is, every- 
one who wants a job at the market wage rate has one, we assume: (1) prices and nominal wage changes are correctly anticipated; (2) all labor is homogeneous; and (3) there are no market imperfections.

The correct anticipation of wages and prices means that each firm and each worker has such knowledge. Wages and prices are flexible both upward and downward. Labor homogeneity implies that each worker is like that of every other in terms of such factors as skill, age, and sex. A perfect market is characterized by complete, costless knowledge of job information and unlimited, immediate and costless ability to transfer labor resources from one job to another. There are no artificial impediments to labor opportunities such as a minimum wage law or job discrimination on a nonprice basis. Markets are cleared instantaneously under the assumptions of this simple model (see the fignre below) and, consequently, there is no unemployment. That is, all those who desire to work at the prevaling wage rate are employed.
A downward shift in the demand for labor (brought about, for example, by a long-lasting drop in consumer confidence) results in an excess quantity of labor supplied at the existing wage rate, and an immediate decline in the wage rate occurs to clear the market. The lower rate is immediately recognized by the workers as being widespread, and there is a decline in the total quantity of labor (in man-hours) worked. The fall in the quantity of labor worked may be reHected in fewer hours worked per employee or fewer employees. If no workers decide to drop out of the labor force and all accept the lower wage, the lower quantity of manhours is reflected in fewer hours of work per employee. Still, every worker who wants a job at the lower wage can find one, and a state of full employment is maintained continuously. Those who make the economic choice not to work at the lower rate have left the labor force voluntarily and are not considered unemployed. An increase in the supply of labor, due to a sharp increase in immigration, for ex-

\section{Demand for and Supply of Labor in a Zero Unemployment World}

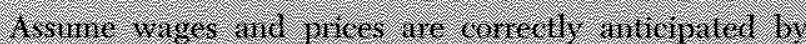

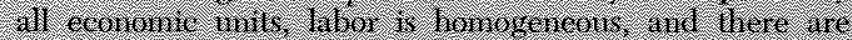

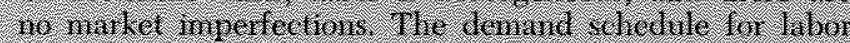

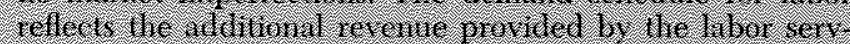

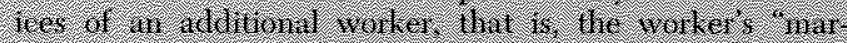

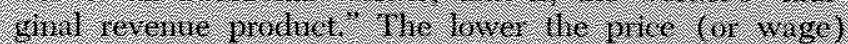

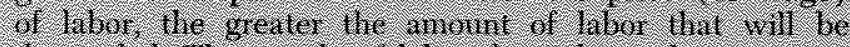

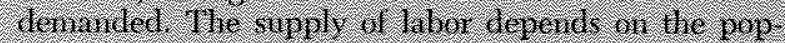

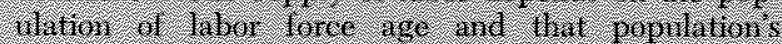

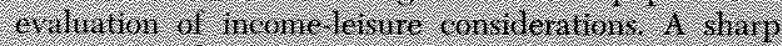

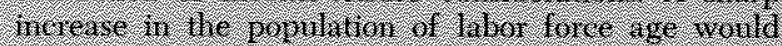

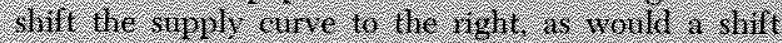

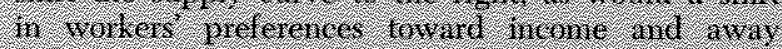
Mon letsure.

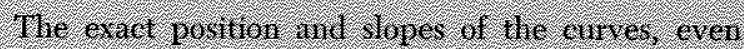

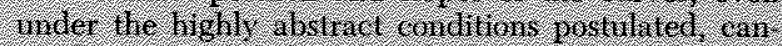

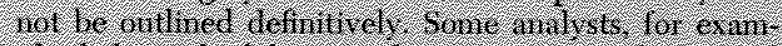

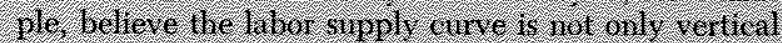

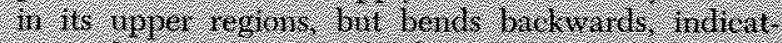

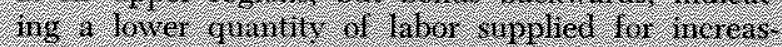

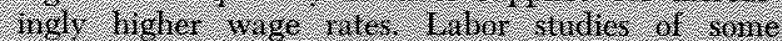

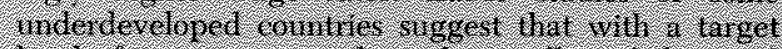

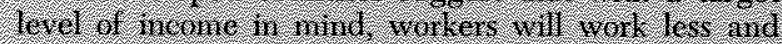

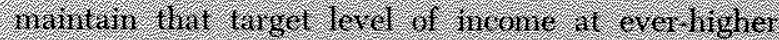
Nage vites

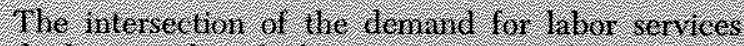

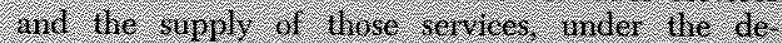

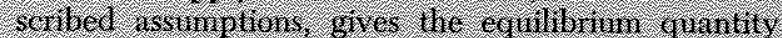

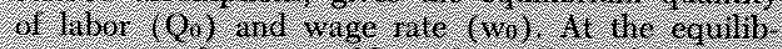

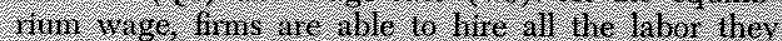

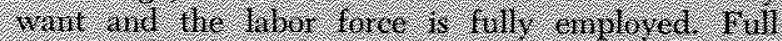

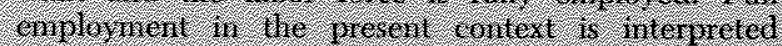

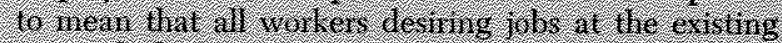

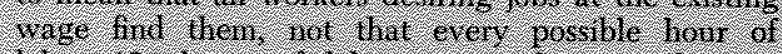

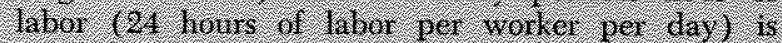
Workera

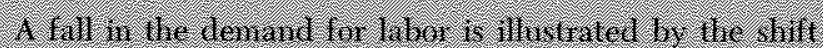

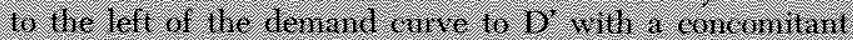

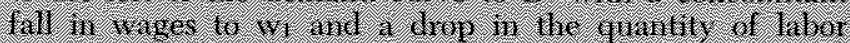

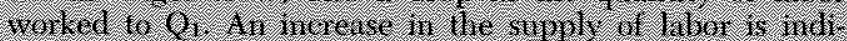

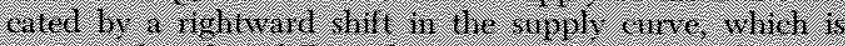

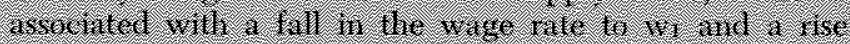

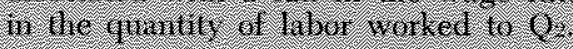

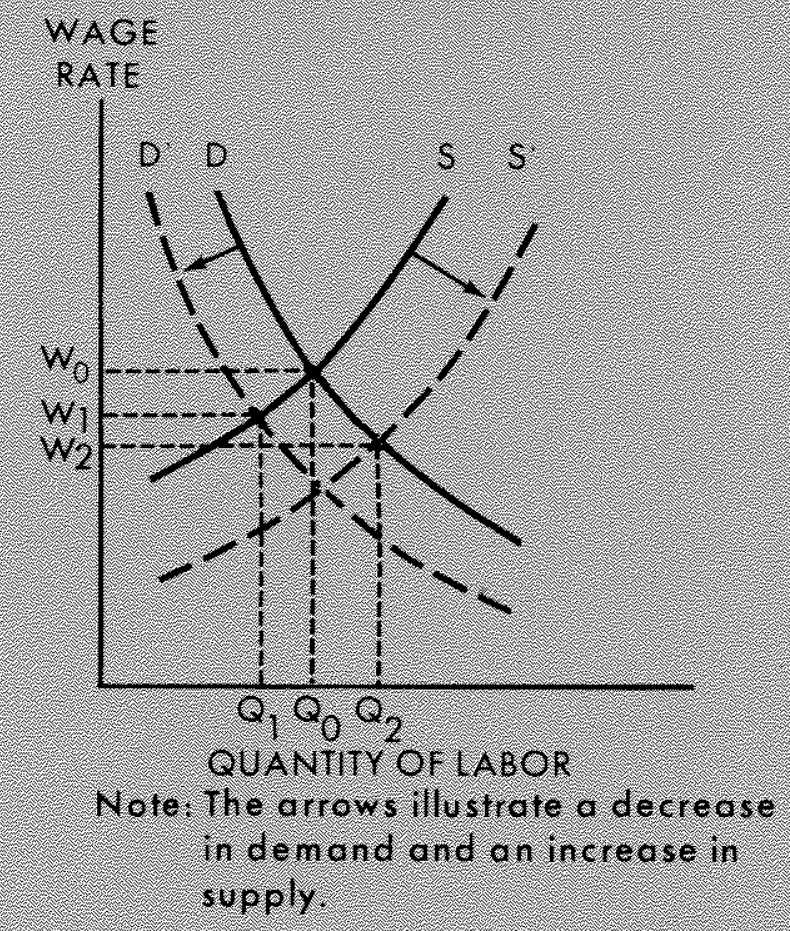


ample, is accompanied by a lower wage rate and a larger total quantity of labor worked. Thus, in this assumed world of perfect labon markets and no costs of adjustment, full employment is maintained confinuously. Although the level of employment may vary, both the market (or actual) rate of unemployment and the nomal rate are zero.

\section{Underlying Cause of Unemployment}

In contrast to the hypothetical world in which there is no themployment, consider the real world stuation in which there is always a positive rate of unemployment: This positive unemployment rate emerges when the rigid assumptions of the "Zero Unemployment World" are dropped. The following Exhibit provides an overview of the causes of unemployment and a classification of the sources. "Sources" refers to the origmal reason for unemployment, that is, why unemployment initially occurs, and "causes" is concerned with its continuance, or why the unemployed individual does not immediately locate a job.

The underlying cause of unemployment is the fact that job information and relocation costs are positive. This lack of perfect (costless) knowledge and mobility means that a worker seeking a job for any reason (better pay, industry lay-offs, downturn in the economy) cannot immediately locate and accept the best employment for which he is suited. So long as there is some service he can perform (whether in the profession or trade in which he is trained, or some other economic services such as manual labor) for some positive wage rate, he need not be unemployed, but he camnot, in general, discover his best employment alternative without some costly period of search.

\footnotetext{
4 According to the Department of Labor, "Unemployed persons comprise all pexsons who did not work during the sirvey week, who made specific efforts to find a job within the past 4 weeks, and who were avalable for work during the survey week (except for temporary illness). Also included as unemployed are those who fid not work at all were available for work and (a) were waiting to be caled back to a job from which they had been laid off; or (b) were waiting to report to a new wage or salary job within 30 days." U. S. Department of Eabor, Burean of Labor Statistics, Employment and Eanings (August 1971), p. 120.

Much of the following analysis (especially those sections on frictional structural and aggregate dernand-related unemployment) is oriented toward explaining the observed unemployment rate as computed by the Bureau of labor Statistics. The costs of infomation and relocation analysis applies not only to this measure of "involuntary" unemployment, but also to voluntary (or hidden) unemployment which is not accounted for in the observed memploymen tate. In many cases, labor market adjustment costs are so high as to discourage potential workers from seeking jobs. An estimate of the significance of hidden umemployment is provided by $\mathrm{N}$. I. Simler and Alfred Tella. "Labo" Re serves and the Phillps Curve," The Review of Economics and Statistics (February 1968), pp. 32-49.
}

During the period of search he is, by definition, unemployed.

The foregoing passage is of sufficient importance to require sestatement. If there is a service of any kind anywhere which an unemployed individual could perform for an above-zero wage, his memployment may be attributed to the fact that he lacks complete knowledge of all job possibilities or that he does not have the resources to permit him to relocate. The unemployed normally prefer to seek jobs in felds in which they are skilled and in favored geographical areas, but after some period of fruitess search, they often scale down their requirements as to work field, geographical location, and/or wage rate.

Since there are positive costs of information and mobility in the labor market, the memployed expend scarce resources (time and money) to locate the vacancy they may eventually fill. Contrary to popular belief, job search (which accompanies nnemployment) is a rational economic decision which often benefts the worker, the firm, and the economic system. The worker is best off (in terms of wealth and utility) by locating the job which offers him the greatest present value as discomted over some finite time span. ${ }^{\circ}$

By taking the first job he is offered, he may pass up jobs which would be more rewarding both monetarily and nommonetarily over his working life. He is most able to obtain a preferable job by a search process which often accompanies unemployment. ${ }^{\top}$ If

TThe significance of information and relocation costs in the determination of unemployment is reflected in the description of the plight of an unemployed husband and his wife in a recent issue of a popelar magarine.

After a month of fruilless job hanting. Tim [layed off from his job as a toolmaker] and Rosemary sat down to consider their alternatives. He could take an unskilled job and supplement it with work in a tool shop. Rosemary could go back to work. They conld move. None of the choices looked good. For Tin to work 60 hours for less than his former pay seemed a drastic lackslide - besides, he would have no time to look for suitable work. Rosemary wants to be home with her children, if possible, at least until theyre all in school. Moving wonld be a terrible sacrifice; ...

Rollie Hochstein, "When the Pay Checks Stopped," Good Housekeeping (September 1971), p. 183.

0The principle that the probability of a worker obtaning the "best" job by taking the first offer is lower than with additional search finds its mirror image with firms and vacancies. A firm has a higher probability of selecting the best applicant for a vacancy by interviewing more than one applicant, despite the fact that the vacancy must remain open for a longer period.

"Gathering and disseminating information about goods or about oneself is in some circumstances more eficiently done while the good or person is not employed, and thus able to specialize (i.e., while specializing in the production of information," Amen A. Alchian, "Information Costs, Pricing and 


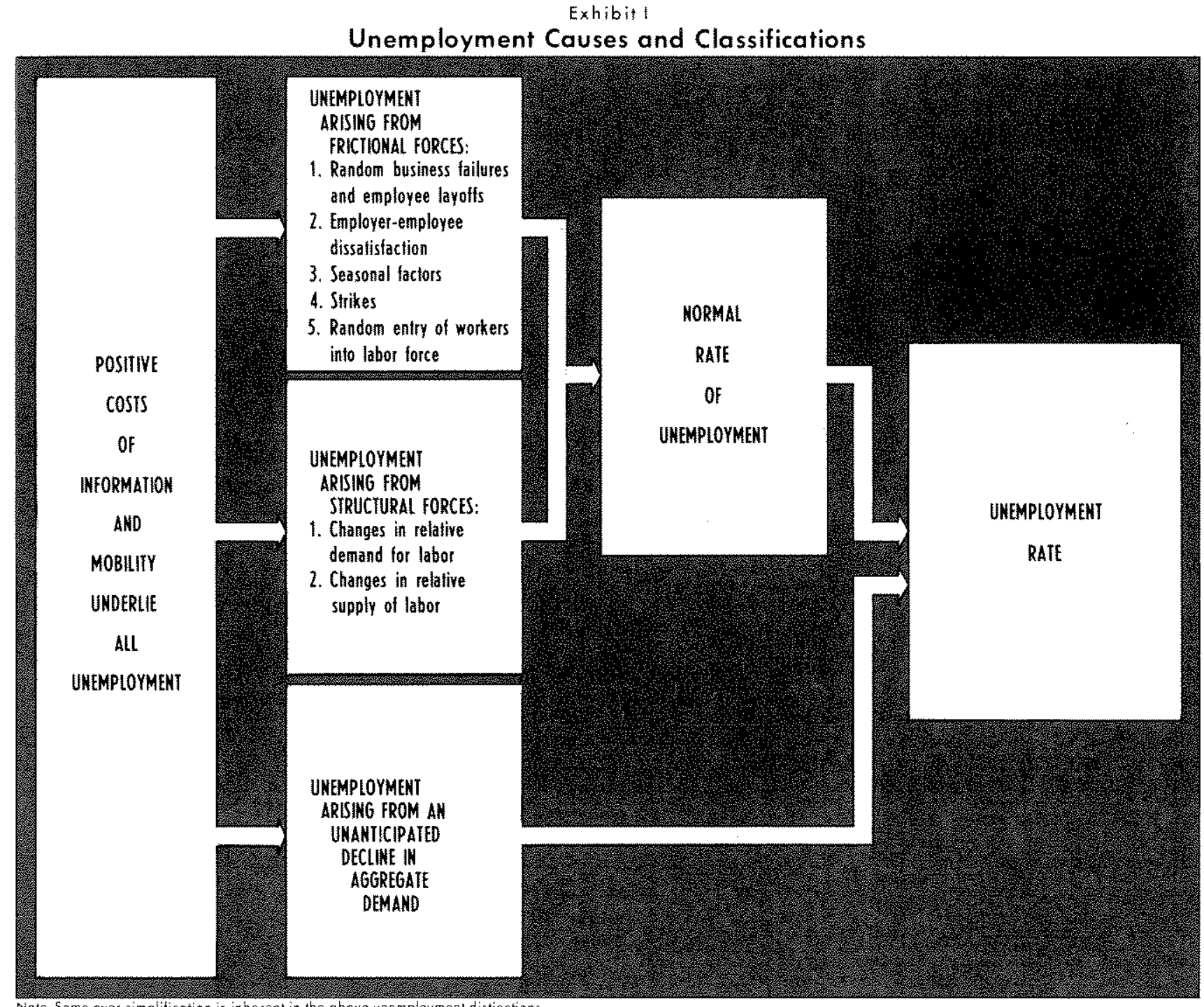

Note: Some ower simplificetion is intherent in the above inemployment distinctions.

Resource Unemployment," Microeconomic Foundations of Unemploument and Inflation Theory, Phelps, et. al. (New York: W. W. Norton \& Co. Inc. 1970 ) p. 29. A large body of literature on the intensity and duration of job search has emerged in recent years. George J. Stigler, in "Information in the Labor Market," Joumal of Political Economy (Supplement: October 1962), pp. 94m105, attempted to find the determinants of worker's wage demands and generated some data which suggested that workers who invested in some job search were better off than those who engaged in virtually no search. Armen A. Alchian and William R. Allen, in University Economics, (Belmont, California: Wadsworth Publishing Company, Inc., 1968), set down several postulates of job search in their text, and Alchian, "Information Costs, Pricing and Resource Unemployment," developed the theory of job search and costs of information more rigorously. Charles C. Holt, in "Job Search, Phillips' Wage Relation, and Union Intuence: Theory and Evidence," Phelps, et. al., related the length of job search to wage aspirations, a concept given more attention heretofore by psychologists than economists. he is well satisfied with the job he takes, (1) his firm will not have to advertise for and retrain a replace. ment for him after a brief period of employment; and (2) society will receive the benefits of a worker who is more productive the more satisfied he is with his position.

The search process is a two-way street - workers search for jobs and firms search for workers. Workers expend resources to secure information about job opportunities, and firms do the same to obtain information on the qualifications of job candidates. Transportation costs are often a part of the search process also. Firms may move plants near available labor 
supply or absorb the costs of employee job transfer. Workers, however, often must bear the monetary and nommonetary costs of obtaining work in other areas.

\section{The Normal Rate of Unemployment}

Given the underlying job search costs, observed unemployment derives from frictional, structural or aggregate demand-related factors. ${ }^{8}$ In addition, the observed unemployment rate may be viewed as consisting of a "normal" rate of unemployment and deviations from the normal rate. The level of the normal rate is detemined by frictional and structural forces (see the Exhibit). The normal rate of unemployment reflects the adjustment of firms and workers to changing economic conditions independent of aggregate demand changes. Deviations from the normal rate may be ascribed to changes in aggregate demand which result in overall prices and wages changing at rates not correctly anticipated by firms and workers.

At the normal rate of unemployment, there is an equilibrium of a particular sort in the labor market. The equilibrium is not one which exists in the sense that the labor market clears at a single wage rate, and there are no excess supplies of or demands for labor.

Equilibrium in the labor market at the normal rate of unemployment is indicative of some average length of search time before a vacancy is filled or, alternatively, a job is taken." This average length of job search at the normal rate is a function of the degree of heterogeneity and imperfection in the job market. In this context, heterogeneity refers to the fact that all workers do not share the same skills and training,

8These are not perfectly separable categorizations, but for expositional purposes, the generalization is useful.

"Since there is not a uriform wage rate at which everyone accepts employment, and market clearance in the usual sense does not occur, it is difficult to depict any sort of realistic labor market equilibritm with a static demand-supply dia gram. Moreover, the equilibrium which exists at the normal rate of unemployment is dynamic and cannot be readily analyzed within the diagrammatica framework of comparative statics. The unemployment rate implied by the intersection of labor market demand and supply curves is zero, a figure not attained in an actual economy.

Holt, p. 58, uses the phrase "stochastic equilibrium" to describe the near equality between the large flows of workers into memployment and from unemployment over any period. He points ont that over the conrse of a year, the sum of quits and layoffs is about equal to the sum of new hires and recalls. Phelps, p. 8, discusses equilibritm in the non-Walrasian sense, that is, labor market equilibrim "in the large" which occurs despite the existence of some vacancles and some unemployment. nor do all job vacancies require the same qualifications. Job market imperfections mean that there is not perfect (costless) information about vacancies or qualifications, costless mobility, or equal job opportunities for workers with similar job qualifications.

The normal rate of unemployment at any time is not easily measured, but conceptually it can be defined as that rate which exists (given labor market imperfections and heterogeneity) when wages and other prices conform on average correctly with anticipations. Some firms and workers underestimate price and wage changes and some overestimate, but on average for the overall economy, prices and wages are correctly foreseen. Since the wage rate associated with vacancies at some firms will be below the rate expected by some applicants, these applicants will continue to search for higher wages. ${ }^{10}$ During the period of search, these particular applicants are unemployed, and their unemployment constitutes the normal rate of unemployment. Other applicants, however, are pleasantly surprised that the wage rate associated with a particular vacancy is higher than they anticipated. Their search time is shorter than the average associated with the normal rate of unemployment.

When nominal wages are rising faster than anticipated on average, job search time on average falls and there is "over-full" employment, that is, a fall in unemployment below the normal rate. When wages are increasing slower than anticipated on average, there is less than "full" employment, as unemployment rises above the normal rate. The normal rate itself varies with changes in the amount of frictional and structural unemployment.

\section{Frictional Sources of Unemployment}

Workers who are unemployed for short periods due to "standard" market adjustments are frictionally unemployed. Standard market adjustments refer to those situations in which workers enter the job market with little experience, quit jobs voluntarily to look for better ones, or are released from employment due to employer-employee dissatisfaction, strikes, seasonal factors, or business failures unrelated to changes in aggregate or relative demand. Frictional unemployment, characterized by a continual churning of jobs and workers, is basically institutional in that a so-

\footnotetext{
10The expectation of a higher wage than is offered is also a proxy for other reasons that a job seeker is not hired. For example, in the cases of both frictional and structural unemployment, the actual wage associated with a vacancy may be zero for inqualified applicants.
} 
ciety's laws - both those of man and nature - govern its degree. The existence of frictional unemployment arises with the relaxation of only one of the assumptions made in the discussion of the zero unemployment model-labor market imperfections. ${ }^{11}$

The following example illustrates the interplay of frictional sources and search and information costs in bringing about unemployment. If a worker is released from his job because of a strike in an industry which supplies his employer's firm with materials, he probably will not know whether he can get a similar job with another firm, or in another field, or with his own firm after the strike is ended. That is, he does not have perfect job market information. He is temporarily unemployed while seeking a similar job with another firm, or a different job in another field, or waiting to be called back to his old job. If he had complete information on all alternative employment opportunities, he could take the best job situation, but the absence of such information often requires costly search and/or relocation. Strikes, bad weather conditions, a jump in the number of random business failures, increased random worker entry, and worsening overall employer-employee relations lead to higher frictional unemployment and a higher normal rate of unemployment (because frictional unemployment is a major component of the normal rate of unemployment).

Such unemployment is basically a product of the institutional setting of the labor market. Changes in the institutions lead to changes in the degree of frictional unemployment. Since institutions change slowly, frictional unemployment probably does not tend to vary a great deal. If, however, there is a long-lasting change in, say, labor laws which affect the propensity to strike, or weather conditions which permanently change rainfall patterns, or communications developments which alter job information costs, there will likely be a permanent change in frictional unemployment and the nomal unemployment rate. Aggregate stabilization policies could do little to alter unemployment arising from institutional sources.

\section{Stuctural Sources of Unemploument}

Unemployment resulting from shifts in relative demands for and supplies of labor is attributable to structural factors. These shifts are of sufficient magnitude to constitute a shock to the economic system, as opposed to the steady chuming that marks fric-

\footnotetext{
1xContinuing the parallel with the zero memployment world assumptions, structural unemployment is marked by dissimilarities among workers (labor heterogeneity), and unemployment arising from aggregate demand-related sonces is attributable to incorrect anticipations of prices and wages.
}

tional unemployment. Relative demands change due to technological advances, changes in tastes, or depletion of a natural resource. Relative supplies may change with shifts in particular categories of workers (such as a large increase in sixteen-year-olds initially entering the labor force), minimum wage increases, or changes in the ability of some groups (such as unions) to alter the supply of labor in particular fields. Since the shifts in either demand or supply (and the degree of the shift) are not immediately evident to all workers, unemployment often arises as workers (and relative wages) adjust to the shift. Search costs are incurred during the period of adjustment.

Institutional factors are often responsible for shifts in labor supply much as with changes in frictional unemployment. A one-time-only change in the birth rate (which affects the size of the labor force sixteen years later) or military employment (which affects the civilian labor force, and, in turn, unemployment) gives rise to temporary changes in structural unemployment and the normal rate of unemployment. A long-lasting change in the birth rate (due to advances in birth control technology, for instance) or military requirements (due to war or threats of war) would tend to have a long-lasting influence on unemployment.

Changes in relative demand, however, are not likely to have a permanent effect on unemployment, because the affected workers eventually adjust to the demand shift. Workers who becone unemployed because of a drop in the demand for their particular skill (due to, for instance, technological advances or changes in taste) may alter their skills over time. Also, a long-lasting shift in demand is likely to discourage workers from entering the field in which demand declined. By way of contrast, there is little on the supply side that sixteen-year-olds, for example, can do to enhance their employment opportunities. Moreover, workers camnot be "discouraged" from reaching the age of sixteen. Examples of the demand and supply shifts should help to illustrate unemployment catsed by structural changes.

Shifts in relative demands for labor - Technological advances in the transportation industry have been accompanied by substantial shifts in the demand for particular types of transportation workers. The demand for ferryboat operators, pony express riders, and strectcar conductors has declined in the last century, while technological advances have created a demand for bus drivers, truck drivers and commercial airline pilots. In some cases, workers may be able to retain 
jobs in their particular field by lowering their wage demands, but in other instances, jobs become unavailable regardless of the wage decline a worker is willing to accept. ${ }^{12}$ The latter is the more likely case when workers' wages are a relatively small portion of the overall cost of providing a good or service. Large fixed (nonlabor) costs are typically characteristic of the transportation industry.

In those cases in which a worker could retain his job by accepting a wage cut, he will often prefer to look elsewhere for employment in his own field or take a job not in his primary field. He may look for a job requiring little or no skill (and accept the commensurately low pay) to obtain employnent quickly and/or retrain himself in another field in order eventum ally to take a job paying skilled labor wages.

When a blacksmith, railroad fireman or ferryboat operator is told he must leave or accept a pay cut, he may not realize that demand for his particular accupation has fallen everywhere, not just within his own firm. It will probably take him some period of search to learn that the fall in demand is pervasive. Such unemployment is generally reduced over time as workers adapt to the changed composition of demand for their services. Hence, unemployment resulting from a change in relative demands for labor is temporary.

The effect of the changed composition in demand can also be illustrated by considering a change in tastes. If the public, through its representatives in government, decides to lower its demand for government-employed engineers and increase its demand corresponkingly for government-mployed school teachers (aggregate demand remaining the same), a likely result is that unemployment among engineers will rise, as will vacancies in the teaching feld. The cutback in demand for engineers is reflected in both a less attractive wage and fewer hours of work required in that field. If each engineer were willing to take a wage cut ${ }^{13}$ and/or if each engineer-

12Unemployment compensation provides a partial lower limit for the waye cut a worker is likely to consider.

13 Acceptance of a wage cut by employees may at first appear somewhat anrealistic, but workers in the recent past bave taken such ats to avoid losing their jobs.

In recent months, such diverse groups as taxi drivers in Cleveland, paper mill employees in New York, and watchmakers in Pennsylvania have taken pay cats, some on a temporary basis. Now there's talk of wage-cutting among many of the 11,000 hourly workers at General Motors Corporation's Frigidaire Division in Dayton. It's still too early to call wage-cutting a trend. But both unim officials and corporate labor experts in a number of industries concede that if the economy stays in the ing firm reduced the hours of work required equally for all engineering employees, there would be no change in the number of people employed in engineering. In practice, however, the engineers will probably not realize until after some period of search that the decline in demand is not restricted to their firm alone, but is widespread. Also, the firms normally do not ask all their employees to work say, six hours, instead of eight; the firm accepts a reduced number of employees working the full eight-hour day.

Eventually, the engineers learn of the permanent decline in demand in their own field after some period of costly search, and take employment in other occupations for which they may be qualified, or retrain themselves to become, say, school teachers, ${ }^{1.4}$ The unemployed engineers may well have to move from their home area, particularly if government demand for engineers accounted for a sizeable portion of jobs in that area, to another location to find employment. ${ }^{15}$ After such adjustments they are once again employed.

doldrums, they may be forced to join the list of businesses that have already whittled pay checks.

Jim Hyatt, "Some Workers Accept Pay Cuts as Alternatives to Losing Their Jobs," The Wall Street Joumal (July 23 , 1971 ), p. 1 .

1:The situation of the unemployed toolmaker described in footnote 5 also provides an illustration of the case in which workers, after some period of unsuccessful search for work in their own field, switch to other occupations. With his unemployment benefits about to run out,... "IIs [Tim's] choice then may be to take a job, any job, or go on relief. He knows he will choose to work. Meantime he has applied for a job on the Trumbull police force. As a policeman he will not approach his AVCO Lyconing salary, but the rem spectability and security of that job appeal to hin. Furthermore, he expects that the working hours will leave time for a second job." Hochstein, p. 184.

Another example is provided by the experience of recent college graduates who have had diffeulty locating jobs in their field: "Most resist it, but sooner or later those college graduates] who can't land a desired position or one even vaguely related to their field of study wind up considering something like secretarial work, driving a taxicab or waiting on tables" Gary Ronberg "Many College Craduates Jobless After Trying for 3 Months," St. Louis Post Dispatch (September 7,1071 ), p. 3 .

15There some question as to whether a worker who is gualified for a vacancy in an area not immediately accessible to him is frictionaly or structurally unemployed. From the worker's point of view, if he must bear excessive moving costs, he is structurally unemployed since the costs of relocation make him, in effect, unqualified (or unavaikble) for the vacancy. Assuming the firm would employ the worker if he were available, they would probably consider him frictionally memployed.

Structural and frictional unemployment are not only related to each other, but also to aggregate demand-related unemployment. For example, an expansionary policy action which rosters a higher level of aggregate demand also tends to create more job vacancies in all occupations. Increases in vacancies will tend to lower structural unemployment because there will be, other things equal, more vacancies for which there are qualified job applicants. 
Shifts in relative supplies of labor-One important way in which unemployment due to structural factors is aggravated is through limitations on the supply of qualified workers. At any time in an economy, there are workers in the labor force who are unable to obtain jobs in a particular field because of artificial barriers to entry. These workers (1) are qualified to fill a vacancy, but are kept from filling the vacancy by unions, formal lobbying groups, loosely organized associations of workers or "concemed citizens" or (2) would be qualified to fill the vacancy if it were not for the hindrance of such groups.

Unions, for example, have some control over the size of their membership. If they were to restrict the size of their membership, they would be able to enhance the wage earning power of the current mem bers. ${ }^{1 *}$ To see how the ability to restrict labor affects unemployment, take the example of a carpenter newly arrived from another country. If he is prohibited from entering the local union, and if the unton controls most of the carpenter jobs (that is, determines who fills the vacancies and how many vacancies will be left temporarily unfilled), he will not be able to obtain work as a carpenter immediately. As a result, the immigrant carpenter is unemployed while he attempts to enter the mion, seeks nonumion work in his own field locally or in other communities, or seeks work in other fields. With union control of vacancies being continualy encountered by different workers over time, there may be at any time some unemployment attributable to union influence. Structural memployment and the normal rate of unemployment may rise with an increase in union ability to control jobs and fall with a decline in that ability.

The prevention of blacks, women and others by any group from gaining qualifications for work through training programs may also be interpreted as givm ing rise to structural unemployment. If the worker were permitted to increase or upgrade his work skills, he could find more vacancies for which he would be qualifed and, quite likely, reduce his unemployment search time. The costs of search underlie uncmploy-

\footnotetext{
1 No attempt is made here to criticize unions or any other groups. The power to control labor selpply does not necessarily mean such power is inevitably exercised. We auree with the Committe for Econonic Development that "Unions should be able to give adequate expression to the legitimate interests of their members. At the same time, steps must be taken to assure that they do not have excessive powers to restrict the supply of labor through such means as outdated apprenticeship reouirements or racial discrimination, nor the power to place undue restrictions on productivity improve. ments." Comonittee for Economic Development, Further Weapons Against Infation (November 1970), pp. 18-19.
}

ment arising from frictional, structural, or aggregate demand-related somces.

Unions are not the only groups who may effectively curtai job entry. The practice of licensing job applicants to insure that qualitative standards are met is accompanied by the power to control entry. Those in charge of the licensing are often affliated with the group in whose interest it is to limit the supply of workers. These groups may range from doctors to taxi drivers. One analyst, for example, found evidence suggesting discrimination by doctors against admitting Jews to medical schools for fear they might become price cutters, ${ }^{ \pm 7}$

Besides hicensing, other legal means of curbing the effective strpply of workers include such laws as national and state minimum wage regulations. These laws are designed to set a floor under particular wage rates, but a side effect is a tendency to aggravate unemployment. A young, inexperienced worker entering the labor force for the first time might be able to contribute something to the value of a firm's ottput, but if his contribution to the firm is not worth the minimum wage, he is not likely to be employed. The young worker may eventually find a job, but the tendency of the law is to lengthen his search time beyond what it would be without the law. That is, it is an additional factor tending to lengthen his search time, and consequently, his period of unemployment. Thus, an increase in the minimum wage (so long as it is higher than the value of the worker's contribution to the firm) increases the normal rate of unemployment. Those most adversely affected by the minimum wage are the young, the old, the disabled, the meducated and the disadvantaged. ${ }^{18}$

ETRerben A. Kessel, "Price Discrimination in Medicine," The Joumal of Law and Economics (October 1958), pp. 20-53.

16in profitable periods, firms may hire such workers to improve their image, but during cyclical downturns, these workers are often the first to be released. Miltor Friedman and Yale: Brozen, in "The Minimm Wage Rate - Who Really Pays? An Interview with Yale Brozen and Milton Friedman," Free Society Association, Inc. (Washington D. C., 1966), conterd that the mininum wage has a strong adverse effect on black unemployment rates. Other evidence of possible detrimental minimum wage effects on memployment has been found by John M. Peterson, "Employment Effects of State Mininum Wages for Women: Three Historical Cases Re-examined," Industrial and Labor Relations Review (April 1959), pp. 406-422; Colin D. Campbell and Rosenary G. Campbell, "State Minimum Wage Laws as a Canse of Unemployment" Southen Economic Joumal (April 1969), pp. 323-332; H. M. Douty, "Some Effects of the $\$ 1.00$ Minimum Wage in the United States," Economica (May 1960), pp. 1374147; Arthur F. Burns, The Manastement of Prosperity (New York Columbia University Press, 1966); and William I. Shkurti and Belton M. Fleisher, "Employment and Wage Rates in Retail Trade Subsequent to the 1961 Amendments of the 
The nomal rate of unemployment, in summary, tends to rise with increases in information and moving costs, unanticipated changes in tastes and technological developments, and certain shifts in the supply of labor. These factors help explain the existence of a variable normal rate of unemployment, but deviations from the normal rate itself can best be explained by changes in aggregate demand.

\section{Deviations From the Normal Rate of Unemployment}

If aggregate demand is rising at a steady rate such that wages and prices are anticipated correctly on average (some overanticipation and some underanticipation), unemployment is defined to be at its normal rate, and there exists a state of equilibrium "in the large." Policy actions which slow the rate of growth of aggregate demand, so that wages (and prices) rise less on the average than anticipated, cause unemployment to rise above the normal rate. These actions, like shifts in the relative demands for and supplies of workers, are of sufficient magnitude to constitute a shock to the economic system. Policy actions which stimulate the rate of growth of aggregate demand, so that wages (and prices) rise faster on the average than anticipated, push unemployment below the normal rate. These two cases are explored more fully below.

\section{Unemplotment Above the Normal Pate}

Starting at a condition of equilibrium in the large with unemployment at the normal rate, the slowing of aggregate demand growth by, for instance, restrictive monetary actions, results in a decline in the demand for labor. Employers at first may reduce output by cutting back overtime and not filling vacancies created by normal attrition. If the slowing of aggregate demand is more than temporary, employers will have to reduce output and their wage bill by dismissing workers or possibly asking them to accept

Fair Labor Standards Act," Southem Economic Joumal (July 1968), pp. 37,48 . Criticism of such studies usually has emphasized that the causes of tmemoloyment are difficult to unravel, and that the statistical technicues employed to do so are inadequate.

The minamum wage also has the potential to aggravate inflation, since raising prices is one alternative which firms have to meeting increased labor costs. Firms may meet the rise in labor costs eaused by the minimum wage-which often fosters an upward shift in the firm's whole wage structure - by reducing profits, increasing efficiency, rasing the prices of their products, redicing the quantity of labor worked, or any combination of these. Fims which, for various reasons, are achieving low profits, or already are operating at peak efficiency, would have only the options of increasing unemployment or prices. The increase in prices would be permanent if validated by expansive policy actions. lower wages. Because they do not have complete information on labor market conditions, many workers will seck employment at their earlier, higher wage level and will not discover for some time that overall prices and wages have fallen.

Prices may well fall relative to wages (an increase in the real wage rate) initially, because wage contracts are often of a longer-run nature than commodity prices. ${ }^{19}$ A rise in the real wage rate (a lag of wage changes after price changes) is not necessary for an increase in unemployment. All that is necessary is a Iag in workers' realization of the fact that a widespread decline in the demand for labor has occurred. The costs of acquiring information about job vacancies increase for workers, since employers will have reduced their outlays, such as advertising, for recruiting new employees. Unemployment, which rises with the increased costs of information, will continue to rise until workers decide to accept employment at the new, lower money wage rate." The workers, as a whole, revise their wage expectations downward over the period of increased unemployment less than in proportion to the actual fall in wages."

Not until anticipated wage (or price) changes equal, on average, actual wage (or price) changes,

19The cyclical relation between employment and the real wage has long been of concern to economists. Keynes assumed an inverse relationship between employment and the real wage, but subsequent empirical studies provided little support for his thesis, See Ronald G. Bodkin, "Real Wages and Cyclica" Variations in Employment: A Re-Examination of The Evidence," Canadian Joumal of Economics (August 1969), pp. 353-74. Barro and Grossman synthesized the work of Patinkin and Clower to develop a macroeconomic model in which imemployment may be explained without resort to real wage movements. Robert I. Barro and Herschel I. Grossman, "A General Dísequilibrium Model of Income and Employment," The American Economic Review (March 1971), pp. 82-93. Note that real wage changes are not an essential feature of the analysis given above, but provide a supplementary explanation of cyclical memployment. "the lag in workers" realizations of a pervasive change in aggregate demand behind the actual change is the essential feature.

20The failure of workers to realize the pervasiveness of the decline in demand for their services is often interpreted to represent a "money illusion" on the part of the workers. The fall in prices will have increased their real (price-defiated) wages, but because money wages have fallen, workers will prefer to continue job search rather than initially accept the lower wages. There need be no irrationality on the part of these who continue their job search: they simply lack the complete information on which to base job search decisions. The acquisition of that information is often costly and time consuming.

21Some workers become discouraged enough about the wage and employment situation to drop out of the labor force and accept leisure instead. On the other hand, some members of the household who do not normally work for wages, such as housewives and students, will enter the labor force during slack periofts to augment the household's income, The evidence on balance indicates that more workers are discouraged from working in a slack labor market than are encouraged to work, See Simles and Tellat, pp. 32-49. 
will unemployment return to the nomal rate. Stabilzation at the normal unemployment rate will occus eventually unless monetary growth, and hence aggregate demand, not only declines but continually decelerates so that, on average, actual wages continually fall faster than expected wages.

\section{Unemployment Below the Normal Rate}

With unemployment initially at the normal rate, an increase in the rate of growth of the money stock will increase output, prices and the demand for labor. Initially, money wages rise more, on average, than anticipated, thereby providing the inducement for the unemployed to stop their search earlier than planned. The shorter average job search time is accompanied by a fall in unemployment below the normal rate. Also, search costs to workers decline as firms, recruiting more aggressively than before the increase in aggregate demand, absorb more of the search costs than previously. Prices may rise faster initially than wages (real wages decline), and many workers evaluate the new, higher money wages at the old price level.

Unemployment will renain below the nomal rate until workers correctly anticipate, on average, the increases in prices and wages. With the realization that a wide-spread increase in the demand for their services has occurred, workers will become more selective in appraising job offers (to obtain the best one), average search time will rise and unemployment will rise to the normal rate. So long as the monetary expansion does not continually accelerate, workers will eventually demand money wages adequate to compensate them for the rise in prices. Real wages retum to their earlier level and employers no longer find additional labor resources attractive. Growth in the demand for labor falls and unemployment returns to its nomal rate.

Only if monetary growth accelerates will anticipated wages continue to increase less, on average, than actual money wages. Unemployment can be kept below the normal rate in this way, but the cost of continged monetary acceleration is the continued ac-

\footnotetext{
${ }^{22}$ Studies supporting the "accelerationist hypothesis" can be found in Milton Friedman, "The Role of Monetary Policy," The American Economic Review (March 1968), p. 10; Ed. mund S. Phetps "Money Wage Dynamics and Labor Market Equilibrim," Phelps, et. al.; and Nobert $\mathrm{E}$. Lucas, Jr. and Leonard A. Rapping, "Price Expectations and the Phillips Carve," American Economic Review (June 1969), pp. 342 50. Some additional empirical evidence is provided in the final section of this paper. For an opposing vew, see Robert M. Solow, Price Etpectations and the Behavion of the Price
}

celeration of price rises t:- The cost of reducing job search time for a small minority of unemployed is excessive inflation for all. Job search time for such a group can be reduced by more efficient methods than nonetary acceleration, as will be discussed below,

\section{LEGISLATIVE, FISCAL AND MONETARY POLICIES TO REDUCE UNEMPLOYMENT}

Legislative and allocative fiscal actions can best be used to lower the normal rate of unemployment, and monetary actions can foster a stable climate for prices consistent with a prevailing nomal rate of unemploy. ment.:-3 Legislative actions which would reduce monopolistic powers of employers and unions in a world in which the costs of information are positive would tend to lower the nomal rate of unemployment. Stronger legislation to eliminate job discrimination on nomprice grounds and improve the overall functioning of labor markets are examples of actions which could be taken by law-making bodies to improve the employment outlook. Legislation to mitigate the negative employment impact of the minimum wage would be particularly helpful to the young, the old, the inexperienced, and the disadvantaged.

Alocative fiscal policies could be oriented toward lowering the normal rate of unemployment by transferring government resources from a sector distantly related to employment, such as foreign aid, to direct employment assistance. One way of lowering the normal rate would be through actions designed to lower the costs of information and job transfer. ${ }^{24}$ Job infor-

Level, (Manchester: Manchecter University Press, 1969), p. 17: and Robert I. Cordon, "The Recent Acceleration of Intlation and Its Lessons for the Future," Brookings Papers on Economic Activity (1:1970), pp. 8-47.

${ }_{23}$ A locative fiseas actions are those designed to affect activity in a particular sector of the economy; aggregative fiscal actions are taken to influence overall activity.

* Since unemployment associated with changes in aggregate demand is also ultimately related to information and mobility costs, a decline in these costs could help to lower aggregate demand-related unemployment. Under certain con* ditions, however lower information costs may not lower unemployment. See Phelps, et, al, p. 18. Govermentsponsored prograns to provide statewide information on job vacancies are curfently operational in a number of states. Not enough experience with the programs has yet been gained to assess adequately their contrbation to employment assistance.

Other proposals which would have the effect of lowering the normal rate of unemployment have been introduced by the "Report of the Foint Economic Committee, Congress of the United States, on the Febnary 1971 Economic Report of the President," and the Committee for Economic Development, Further Weapons Against Inflation (November 1970). p. 18. The Joint Economic Committee relies strongly on a proposal for a price-wage review board to maintain stable prices in the face of high employment. However, there is 
mation banks, training outlays and relocation subsidies could reduce the search time of workers between jobs and possibly increase the rate of growth of income because of a more efficient utilization of resources. Such policies to reduce the normal unemployment rate need not cause inflation.

Inflation, as discussed in the preceding section, results when monetary actions are taken which push the market rate of unemployment below the normal rate. Stimulative monetary policies may be appropriate when resources are underutilized and the market rate of unemployment is above the normal rate, but the temporary employment gains achieved by monetary actions when unemployment is already at the normal rate are offset by rising prices. Experience of the last two decades indicates that the use of monetary actions to reduce unemployment when it is above the normal rate runs the risk of creating inflationary pressures. First, there is not sufficient knowledge with regard to the existing level of the normal rate at any point in time, and second, stimulative monetary policies often have been carried on too long. Therefore, the proper role of monetary policy is the creation of an atmosphere of stable prices, while fiscal and legislative actions can be taken to lower the normal unemployment rate.

The normal rate of unemployment may rise in the near future unless legislative and fiscal actions are taken to counter such a tendency. In the decade of the 1970 's, an increase in the supply of available labor is expected because of the increase in the population of labor force age, much of which will be attributable to young people. ${ }^{25}$ Also, increases in labor force participation rates, particularly women and nonwhites, and expected reductions in military calls of draft-age males will tend to increase the civilian labor force. Attempting to lower the unemployment rate through monetary actions alone entails the risk of generating inflationary pressures. ${ }^{2 * i}$

little evidence that such incomes policies conld exercise much long-lasting restraint on prices and wages, especially during periods of high employment. See Lloyd Ulman and Robert J. Flanagan, Wage Restraint: A Study of Income Policies in Westem Europe (University of California Press, 1971), especially pp. 223-8.

250The population of working force age 16 to 24 years old is expected to increase in the 1970 's at a rate faster than during the 1945-60 period but slower than during the $1960^{\prime}$ s. The population of such young people actually declined in 1952 and 1953 , when the overall unemployment rate last reached the 3 per cent level. The inemployment rate for workers aged 16 to 24 averages much higher than the overall unemployment rate. Since males between the ages of 25 and 54 are designated "primary workers," the young people are a part of the large group often termed "secondary workers."

gothe appropriate degree to which monetary actions may be used to reduce unemployment without aggravating inflation is primarily a function of the amount of unemployment

\section{LMMTATIONS OF MONETARY POLICY IN THE ATTANMENT OF THE JEC GOALS}

The use of legislative, allocative fiscal, and monetary policy actions working together is required to attain such ambitious goals as those advanced by the Joint Economic Committee. The fact that legislative and allocative fiscal actions to lower the normal rate of unemployment may be politically unpopular (such as actions curbing the employment influence of unions and minimum wage laws) tends to throw the burden of achieving these two admirable economic goals on monetary policies alone. In order to obtain some quantitative estimate of the implications of altering price and employment movements through monetary actions alone, it is useful to employ an econometric model which allows for the impact of monetary actions.

The econometric model of this Bank permits the manipulation of monetary variables to influence unemployment and prices. The model has been explained in full detail elsewhere. ${ }^{27}$ Basically, monetary and fiscal actions (aggregative fiscal actions, not allocative) exercise an influence over prices and unemployment in the model by altering the course of total spending relative to the economy's productive potential. Changes in the rate of growth of the money stock have a positive multiplier effect on the economy, while the net effect of aggregate fiscal actions alone on total spending over time is negligible. Price anticipations are an important feature of the model, forming a part of the linkage between total spending and its division between current prices and output. Changes in actual output relative to potential output provide estimates of the unemployment rate.

traceable to aggregate denand infuences. The discussion of actions to lower unemployment related to aggregate demand as opposed to unemployment fostered by frictional and structural factors finds historical precedent in the "Structural Unemployment vs. Insufficient Demand" controversy of the early 1960's. See, for example, Richard Perlman, Labor Theory (New York: John Wiley and Sons, Inc. 1969), pp. 167-196; and Eleanor G. Gilpatrick, Structural Unemployment and Aggregate Demand (The Johns Hopkins Press, 1966).

${ }^{2}{ }^{i}$ See Leonall C. Andersen and Keit M M. Carlson, "A Monetarist Model for Economic Stabilization," this Review (April 1970), pp. 7-25; and Roger W. Spencer, "Population, The Labor Force, and Potential Output: Implications for the St. Louis Model," this Review (February 1971), po. 15-23. "This econometric model is basically a reduced form model in that it does not develop structurally various submarkets of the economy, such as the labor market for aggregation. Labor market imperfections can be captured by a reduced form model, however, as well as by a structural model. The model does not have the capability to capture the effect of particular legislative and fiscal actions on memployment and prices. For example, actions to lower the costs of information to workers cannot be shown with this model, nor is it likely that such actions conld be reflected adequately by other models. 


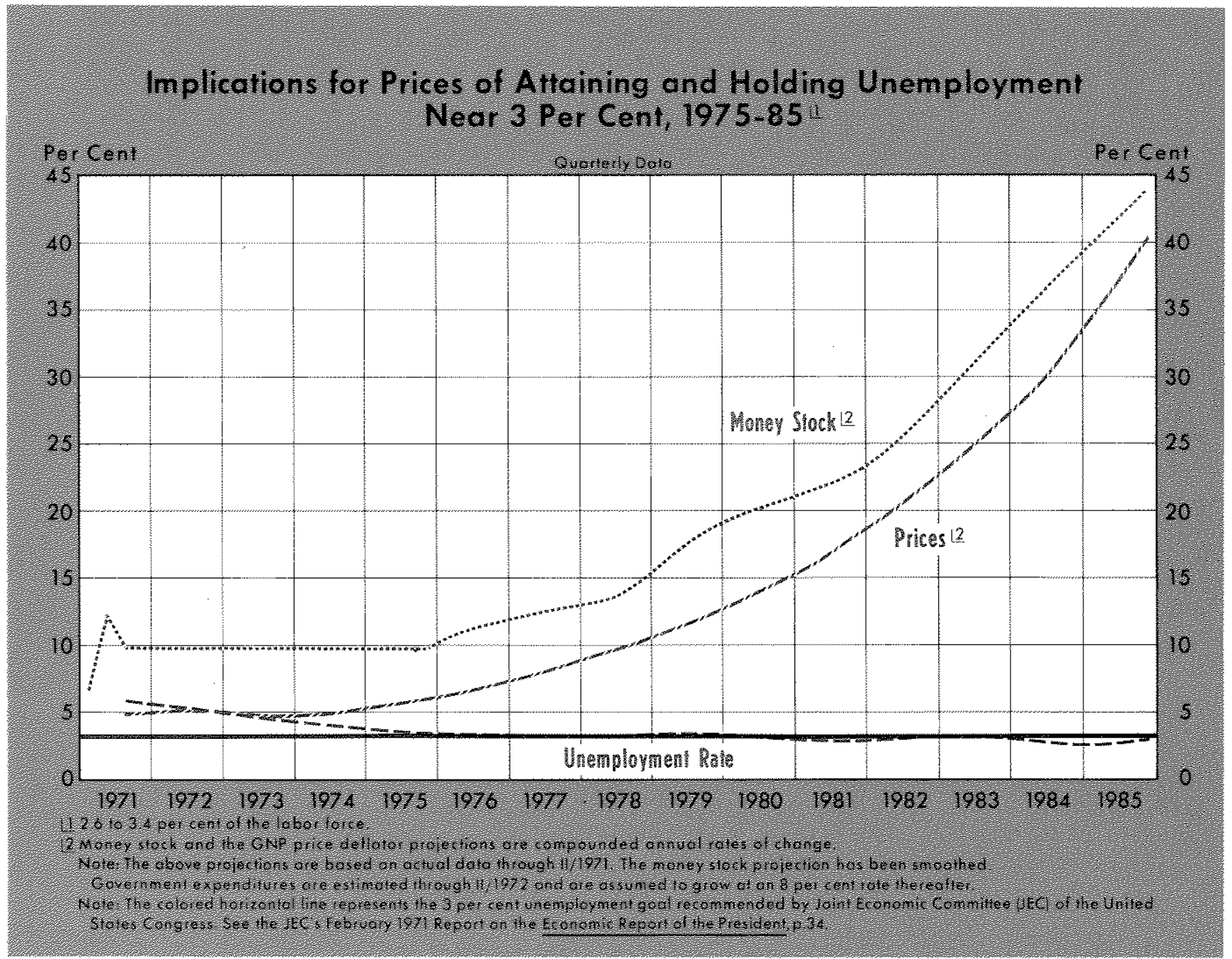

Various monetary policy altematives were attempted through standard simulation procedures to attain simulaneously the Joint Economic Committee's 3 per cent unemployment and 2 per cent per year price goals. These twin objectives could not be achieved at the same time over the arbitrarily selected 1971-85 period, given the current inital coonomic conditions. The goals, however, could be reached individually. Since unemployment considerations have been of dominant concern in this artide, the attainment of a 3 per ent memployment rate was given priority in the following simulation.

It is necessary to wlow some reasonble period of time for memployment to reach approximately 3 per cent of the labor force, becuse a wide gap between potential and real output exists in mid-1971. Increases in the money supply at a 10 per cent ammal rate from $\mathrm{I} / 1971$ to $\mathrm{IV} / 1975$, a period of approximately four years, foster a steady decline in the unemployment rate from 6 per cent in II/1971 to 3.4 per cont in T/1975 (high-employment Govemment expenditures were estmated to II/1972 and assumed to grow at an 8 per cent rate thereafer for all simulations). "Approprate" manipulatons in the rate of growh of the money stock from 1975 to 1985 permit the model to generate memployment rates within a narow range ( 2.6 per cent to 3.4 per cent) near the employment objective for ter years. The attainment of this soal requires acelerning monetary growth from a 10 per cent amual rate in 1975 to a 44 per cent annulal rate at the end of 1985 (see the above chat for the rates of change me money stock), 20 The price level, acouding to the simulation, increases at a 41 per cent anual rate at the end of 1985 . Accelerating monetary growth leads to accelerating inflation - a situation in which actual price rises continue to exced

artitte signifunce should be attached to exact figures such as "d4 per cent" for a fifteem-year simulation. The important ander of this simnlation is that acelerating monetary growth and inflation are required to maintain a 3 per cent unemployment rate. 
anticipared rises - to keep the actual nnemployment rate below some "nomal" rate.

Other altemative simulations which take into account the JUC price goals are explored in the appendix. The price goal of 2 per cent per year is sought after varying degrees of price anticipations are permited to develop. The results of these simulabons suggest that if inflation, as well as unemployment, is deemed an important policy goal, it is far beter (in terms of lost employment and ottput) to attack inflation as early as posible to halt its momentum and curtal intationary expectations.

\section{SUMMARY}

The reasons for unemployment and ways to improve the unemployment situation were explored in this article through the use of an analytical framework based in large measure on the fact that costs of information and job transfer are positive. The conclusion reached is that the nomal rate of uncmploy ment can be lowered by appropriate allocative fiscal and legislative actions; monetary actions are best used to stabilize prices at the lower normal unemploy. ment rate.

Positive costs of infomation and resource mobility, nomprice labor discrimination, and legal constraints on the supply of labor such as minimum wage legistation have cutaled the quantity of labor worked in the past and will, quite inkely, continue to do so in the future. Moreover, expected increases in the supply of secondary workers at apid rate over the next decade suggest shifting the target rate of unemployment above, rather than below, 4 per cent, miess lecrislative and allocative fiscal actions aro taken to curtal labor market costs and restrictons : With such legislative and fiscal actions to supplement monetary actions, a rate of unemployment below 4 per cent might be achieved and nainkaned without genewating strong inflationary pressures.

Given current labor market conditions, it wes not possible to reach simultaneously the font Economic Commitee's twin goals of 3 per cent memployment and 2 per cent anmal rise in proes using simulations of this 3 anks ecomometric nodel wh altomative monetary policies. Atamment of the 3 per cent unamployment mate goal from 1975 to 1985 required accelerating monetary expansion over that period. This expansion was acompanied by accelerating infation - a condtion which implies that actual price rises continue to exced anticipated rises - in order to keep unemploynent below its "nomal rate" The inlation rate required to maintain the 3 per cent memployment rate was so high that it is unhely a price review boaxd as recommended by the Commitee) or any pricenage control measure would succed in stemming such great price pressures.

Two conclusions which emerge from the simulations of the econometric model are: (1) monetary actions must be supplemented by legislative and/or alocative fiscal measures to reach and maintain the Jés goals of a 3 per cent rate of unemployment withot excessive infationary pressures; and (2) if inflation is permitted to develop through attempts to achieve an adminble memployment goal such as that of the $J \mathrm{EC}$, it is better to stem infationary pressures at an early stage than later.

20Gorge L. Perry, "Changing Labor Markets and Infation," Brookings Papers on Economic Actitity $(3: 1970)$ pp. $411-41$ has also developed evidence consistent wh this nypothesis.

\section{APPENDIX}

The am of the following simulations of the econometric model of this Bank is to obtain some idea of the costs of stopping inflationary pressures at various stages of build-up. These costs may be measured approximately by the degree and duration of the rise in unemployment accompanying a fall in the rate of price inflation to the JEC's goal of 2 per cent per year. We may allow for the possibility that after taking actions to achieve the Committee's 3 per cent unemployment goal, the cost in terms of inflation will become sufficiently high for policymakers to alter their focus from the unemployment goal to price stability,

By assuming that inflation costs have become excessively burdensome by 1980 (after 5 years of 3 per cent unemployment and a peak 14 per cent rate of inflation to cause a shift from easy to tight money, it is possible to track the movements of the pertinent variables from 1980 to 1985 , as the stabilization authorities attempt to achieve a 2 per cent annul price rise by the end of the five-year period. A deceleration in the anmal growth rate of the money stock from about 19 per cent in 1980 to a negative 6 per cent in 1985 (see the lower portion of the next chart) is required to slow the advance of prices from 14 per cent in 1980 to 2 per cent in 1985 (because of lags, prices continue to rise from a 14 per cent rate in 1980 to a 16 per cent rate in 1982 before decelerating). Unemployment rises from a 3.2 per cent rate in 1980 to 16 per cent of the labor force in 1985, and real product (not shown on the chart) 


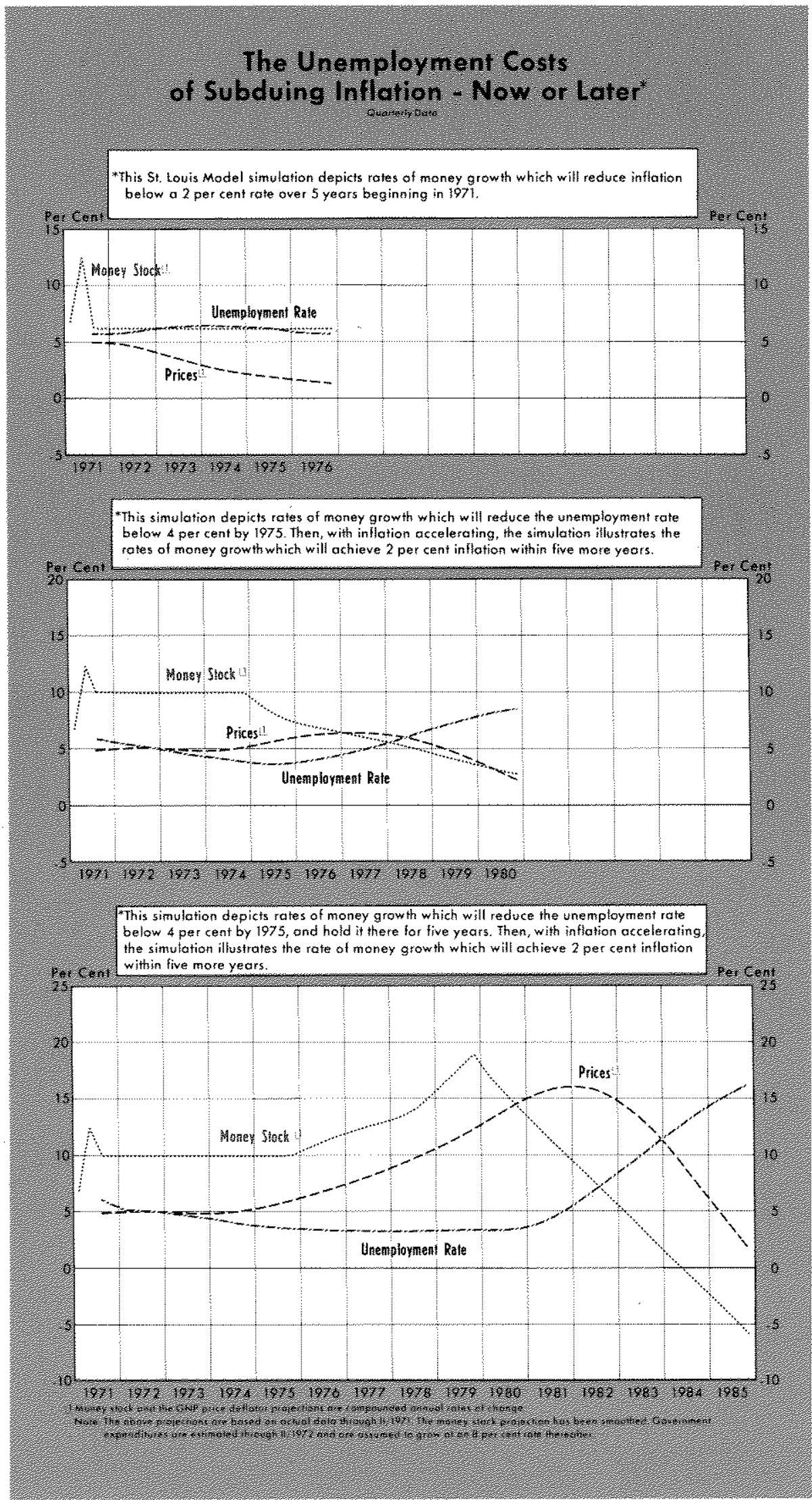

declines in every successive quarter from 1981 to 1985 . The severity of such a recession has been matched in recent years only by the experience of the 1930\%s.

If stabilization authorities decide five years earlier to switch priority goals from unemployment to inflation, and adopt a tight money policy in 1975 (when the unemployment rate is 3.7 per cent and prices are rising at about a 6 per cent rate), it is much less costly to bring prices to the 2 per cent goal over a five-year period. The required deceleration in the rate of growth of money is from a 10 per cent rate in 1975 to a 3 per cent rate in 1980 (see the middle portion of the chart). Unemployment rises to 8 per cent (compared with 16 per cent in the previous simulation), and real output growth never drops below zero. If the money stock is increased at a 6 per cent rate beginning in the third quarter of 1971 , prices fall below a 2 per cent rate by 1975 and the unemployment rate does not exceed 6.3 per cent (see the upper portion of the chart).

The clear implication of these results is that it is far better (in terms of lost employment and output) to attack inflation as early as possible in order to halt its momentum and curtail inflationary expectations.

This article is available as Reprint No. 71 